chemical, mechanical and physical properties ? Is it not one of the main aims of these societies to link up X-ray diffraction with whatever chemical or physical methods seem promising to supplement it? The present circumscription of the societies' activities is decidedly too narrow.

'Crystallography', in its original meaning, does not, it is true, include the entire field of application of diffraction methods. But it covers the main field even then. 'Leptology', which Rinne coined for fine structure ( $\lambda \varepsilon \pi \tau \delta \varsigma$, fine), would be preferable to 'crystallography', but the word has not been generally introduced, and this might not be a good occasion to plead for it. Unless something now is adopted, however, 'crystallography' will have to be used in a wider sense than originally intended, so as to cover substances which for some purposes may be regarded as inferior forms of crystals; in them the arrangement of the atoms or molecules, while showing some kind of regularity, departs further from perfect threedimensional symmetry, homogeneity and periodicity than in the actual piece of quartz to which the name of crystal was originally applied. The remaining regularity may, however, suttce to make profitable a close connexion of substances regarded from this aspect and of the old-time crystals, and it is this enlarged field which the term 'crystallography' should be understood to cover.

\section{'PHENOXETOL' AND OTHER ANTIBACTERIAL SUBSTANCES}

T

HE offensive against pathogenic micro-organisms continues to succeed, and a number of recent articles upon antibacterial substances indicate the widespread interest in them among non-medical workers and also the value of co-operation between scientific men-and especially biochemists-and the medical man. In a leading article last year the Lancet $(781$, June 19,1943 ) discussed the evaluation of wound antisepties and directed attention to Prof. Garrod's review of the recent advances that have been made (Brit. Med. Bull., 1, 48 ; 1943). W. A. Altemeier (Surgery, Gynaec., and Obstetr., 75, No. 6 ; 1942) has published a collective review of the bacteriology of war wounds (see Bull. War Med., 4, 60 ; 1943). Numerous articles in the British Medical Journal and the Lancet keep us continually informed of progress of research on this subject. Referring to the work in Sydney, Australia, of A. Albert, J. E. Falk and S. D. Rubbo (Nature, 153, 712, June 10 , 1944), the Lancet (148, July 29, 1944) discusses the antibacterial action of organic arsenicals such as arsphenamine and neoarsphenamine. Interesting also is the work on sulphasuxidine (suecinyl sulphathiazole), some of which is hydrolysed in the lower bowel with the release of free sulphathiazole, which is effective in intestinal infections. It is stated in the Lancet (544, April 22, 1944) that E. J. Poth and C. A. Ross (Proc. Amer. Soc. Pharmacol. Fed., Baltimore, 2, 89 ; 1943) claim that sulphathalidine (phthalyl sulphathiazole) is two to four times more. bacteriostatic than sulphasuxidine because it is more completely hydrolysed in the bowel. Combinations of sulphathiazole and proflavine in powder form have been recently successfully used by Prof. J. Macintosh and his colleagues (Lancet, 591, May 6, 1944) and by Major G. Y. Feggetter (ibid.; 593). Lieut.-Colonel J. W. Bigger (Lancet, 142, July 29, 1944) records his work on the synergic action of penicillin and the sulphonamides.

Penicillin is, of course, always in the picture. Sir H. W. Florey (Brit. Med. J., 169, Aug. 5, 1944) gives yet another survey of progress of work on its action, and the same issue of that journal contains articles on the use of penicillin in ophthalmology and in acute empyema and on its combination with sulphonamides for the treatment of infantile gastro-enteritis. J. S. Jeffrey and Scott Thomson (Brit. Med. J., I, July 1, 1944) give their experience of the treatment of battle casualties in Italy with penicillin, and in the same issue (p. 15) a leading article discusses an American symposium on the uses of penicillin. In the Lancet (44, July 8, 1944) W. D. Jeans, J. S. Jeffrey and $\mathbf{K}$. Gunders record their treatment in Italy of four cases of smallpox with penicillin. The pustules in these cases contained Staphylococcus aureus, and secondary infection must, these authors think, be responsible for much of the toxæmia in the later steges of the disease. The penicillin treatment was followed by marked improvement, and three of the patients survived, including one who had not been vaccinated. Most of the penicillin used in the Mediterranean theatre of war and for research purposes in Great Britain has been supplied by British manufacturers (Brit. Med. J., 186, Aug. 5, 1944), who are now increasing their production of it: but we owe to the United States the solution of its largescale production and the consequent saving of the lives of many British and American wounded.

Penicillin is, of course, active only sgainst certain species of bacteria. As Prof. Garrod states (Brit. Med. Bull., ii, 2, 1944), most of the species susceptible to it are Gram-positive, and these include the pyogenic cocci Staphylococcus, Pneumococcus and Streptococcus pyogenes, the gas gangrene group of organisms and those of anthrax and diphtheria. The tubercle bacillus and almost all the Gram-negative bacilli, including the typhoid-dysentery group and Brucella, Hoemophilus and those common invaders of wounds Proteus and Pseudomonas pyocanea, which produces blue pus, are resistant to penicillin; but the Gram-negative Gonococcus and Meningococcus are susceptible to it. There is great need, therefore (Lancet, i 85, Aug. 5, 1944), for a substance which will control Gram-negative organisms. In the same issue of the Lancet (p. 175) is an article by H. Berry on the antibacterial action of ethylene glycol monophenyl ether, to which the name 'Phenoxetol' has been given. Prof. A. A. Miles, in his interesting Sydney Ringer lecture at University College Hospital Medical School on the epidemiology of wound infections (Lancet, 809, June 24, I944), points out that Sir Alexander Fleming's work on the bacteriological history of an infected war wound has been abundantly confirmed. Spore-bearing and intestinal coliform bacilli predominate in the first phase; they are replaced by pyogenic cocci in the second phase; and in the third phase these cocci persist and flourish. To them may then be added Pseudomonas pyocyanea and Proteus. Sulphonamides or penicillin will control the cocci, and this is a great advance; but the control of them may enable Ps. pyocyanea and Proteus to become more active, so that healing may be delayed. Berry claims that $P s$. pyocyanea is particularly susceptible to 'Phenoxetol'. The addition of 10-20 per cent of serum in his in vitro experiments with it did not depress its action on this organism, and Berry claims that his in vitro tests suggest that 'Phenoxetol' might perhaps be used with penicillin, the acridine 
compounds (for a discussion of some recent work on these and on some other wound antiseptics see the Lancet, 90, Jan. 15, 1944), the sulphonamides and the quaternary ammonium compounds. 'Phemeride' ('Phemerol') is one of these and its action on bacteria is discussed by C. N. Fland (Lancet, 49, Jan. 8, 1944). It resembles the related substance 'Cetavlon' (CTAB) (seo J. M. Barnes, Lancet, 531, i, 1942, and R. Williams et al., Lancet, 522, i, 1943). Further work on the antibacterial action of organic detergents such as these should be interesting. The toxic action of 'Phemeride' and another detergent called 'Zephiran' on the tissues, and methods of studying their toxic action are discussed in an annotation in the Lancet (188, Feb. 5, 1944), together with work on the effect of antisepties on the metabolism of bacteria.

J. Gough, H. Berry and B. M. Still (Lancet, 176, Aug. 5, 1944) have tried 'Phenoxetol' on wounds, some of which were war wounds, and on burns, tuberculous cavities and cases of infected dermatitis. Most of the injuries treated were granulating areas associated with loss of skin and the need of skingrafting; and these authors are studying combinations of 'Phenoxetol' with penicillin, the sulphonamides and the flavines. They conclude that a daily application of $2 \cdot 2$ per cent solution of 'Phenoxetol' in water reduced the infection with $P s$. pyocyanea or eliminated it and resulted in clinical improvement. The addition of 5 per cent 'Phenoxetol' to the sulphonamide oream, which contains 'Cetavlon', devised by the Burns Unit of the Glasgow Royal Infirmary (see Med. Res. Council War. Memo., No. 10) was tried in vitro and the results were encouraging. But the toxicity of 'Phenoxetol' and its absorption need further study. It would seem that the blue pus of $P s$. pyocyanea, which was so common during the War of 1914-18 and did not then give rise to much anxiety, will shortly be controlled. It is proving, Gough and his colleagues state, an increasing nuisance in plastic surgery and skin-grafting. If future work discovers an opposite number to penicillin which will act with an equal efficiency on the Gram-negative organisms, then the labours of all those who are conducting the offensive against pathogenic micro-organisms will be well rewarded. Their problem will then be the reduction of the censiderable laboratory work which is necessary before a choice of antibacterial substance suitable for each case can be made.

Regulations governing the manufacture of penicillin have been issued by the Government. The manufacture and use of erude penicillium filtrate was discussed by J. M. Alston in the British Mediccl Journal (654, May 13, 1944). A further note in the same journal (314, Sept. 2, 1944) reviews two articles in American chemical engineering journals which describe the great effort which has been made to produce penicillin in quantity; it required the expenditure of millions of dollars at a time (1940 and 1941) when the sceptic might have doubted whether the effort was justified. More than twenty factories have been erected at a cost of gome 20 million dollars. The British Medical Journal (250, Aug. 19, 1944, and 317, Sept. 2, 1944) publishes notes on the use of penicillin for eivilian cases, and the Ministry of Health has issued two memoranda on the use of penicillin now being issued to medicel schools free of charge for the treatment of civilians. Next year there may be enough of it for all requirements. R. J. MeNeill Love (340, Sept. 9, 1944) records one of a number of air-raid casualties to whom penicillin was given as a prophylactic with very gratifying results. In a leading article the Lancet (348, Sept. 9, 1944) further discusses the manufacture and use of penicillin and gives further references. A. Dolphin (Brit. Med. J., 317, Sept. 2, 1944) has described the treatment of ten civilian cases at a meeting of the Fever Group of the Society of Medical Officers of Health, which was opened by Sir Alexander Fleming.

\section{LA SOCIÉTÉ FRANCAISE DE PHYSIQUE}

A $\mathrm{T}$ the meeting of the Physical Society on A November 9, the president, Prof. E. N. da C. Andrade, welcomed some French physicists, members of the sister society, la Société française de Physique. He said : "We have here Prof. P. Auger, Prof. G. A. Boutry and Dr. S. Rosenblum. Through the kind offices of M. Boutry, professeur au Conservatoire national des Arts et Métiers and a fellow of our Society, I have received a brief account of the history of the Société since the outbreak of war. In it the president, Prof. J. Cabannes, records the lamentable fate of many members whose names are known to, and honoured by, all of us." Prof. Andrade then read out the following names of those who had died, the assembly standing :

"G. Dechêne, J. Farineau, H. du Mesnil du Buisson and $J$. Rossignol fell on the field of honour in the early battles.

"F. Holweck, who made his name famous by his pump and by other ingenious instruments, by his work on soft $\mathrm{X}$-rays and by other notable researches, was murdered by the Gestapo; and J. Solomon, one of the most promising of the younger theoretical physicists, was shot by the German military authorities.

"Deaths that we have to deplore, some no doubt accelerated by the traditional brutalities of the Germans, are those of $H$. Buisson, H. Chipart, A. Dufour, A. Guillet, Victor Henri, J. Lemoine, Jean Perrin, Émile Picard and Pierre Weiss.

"Besides those who are known definitely to have lost their lives, there are others whose ultimate fate is unknown. H. Abraham, Eugene Bloch, G. Bruhat, L. Cartan, C. Sadron and J. Yvon have been deported to Germany, and we dare scarcely hope that they have received humane treatment there. Of Paul Langevin, who received in 1940 the highest honour the Royal Society has to give, the Copley Medal, we have no news, unless M. Boutry has something to tell us.

"Let me assure our French friends that although, as Mr. Eden said yesterday, 'People in Britain do not yet fully understand how complete, how merciless, how dastardly has been the devastation inflicted by the German armies in Allied lands as they withdraw', some of us here have some comprehension of German brutality. ..."

Prof. Andrade added that, in spite of obvious difficulties, "all through the troublous days of the German occupation, zealous and courageous French colleagues have kept alive the science of physics in France. In June 1941 appeared a new publication, the Cahiers de Physique; and the first number of another new publication, the Annales de Géphysique, is at this moment in the press. We congratulate our French brethren on the success of their strenuous efforts." 